\title{
The modelling of operation of the compression ignition engine powered with diesel fuel with LPG admixture
}

\author{
G. Pulawski*, D. Szpica** \\ *Bialystok University of Technology, 45C Wiejska Str., 15-351 Bialystok, Poland, E-mail: gpulawski@gmail.com \\ **Bialystok University of Technology, 45C Wiejska Str., 15-351 Bialystok, Poland, E-mail: d.szpica@pb.edu.pl \\ cross $^{\text {ref }}$ http://dx.doi.org/10.5755/j01.mech.21.6.11147
}

\section{Introduction}

The gaseous fuels are used in transportation due to their lower price However, the car manufacturers rarely offer engine units powered with this type of fuel. That is why the row of research courses is run aiming the adaptation different sorts of engines for powering with gaseous fuels, what is connected with the cost increase, thus longer investment return [1-3]. Application the engines to operate on gaseous fuel is related to many problems $[4,5]$. They are mainly: adaptation costs, refilling, engine durability, fuel tank placing, service and operation safety. As fuels capable of transportation usage can be named: natural gas (CNG - compressed, LNG - liquefied), liquid mixture of propane and butane (LPG) and biogas. Basic parameters of these fuels are listed in Table 1.

Table 1

Properties of fuels [1]

\begin{tabular}{|c|c|c|c|c|c|}
\hline Property & Diesel & $\begin{array}{c}\text { LPG } \\
\text { (70\% of butane) }\end{array}$ & $\begin{array}{c}\text { Natural gas } \\
\text { (methane) }\end{array}$ & Biogas & Hydrogen \\
\hline Heating value, $\mathrm{MJ} / \mathrm{kg}$ & 42.50 & 45.78 & 50.00 & 17.50 & 120.00 \\
\hline Heating value of stoichiometric mixture, $\mathrm{MJ} / \mathrm{kg}$ & 2.47 & 2.77 & 2.74 & 2.46 & 3.42 \\
\hline Liquid/gas density, $\mathrm{kg} / \mathrm{m}^{3}$ & $815-855$ & $\begin{array}{l}540 \\
2.06\end{array}$ & $\begin{array}{l}424 \\
0.72\end{array}$ & 1.2 & $\begin{array}{c}71 \\
0.09\end{array}$ \\
\hline Octane number & - & 105 & 110 & 134 & 70 \\
\hline Cetane number & $50-85$ & - & - & - & - \\
\hline Flammability limits, $\%$ & $\begin{array}{l}0.6 \\
6.5\end{array}$ & $\begin{array}{l}2 \\
9\end{array}$ & $\begin{array}{c}5 \\
15\end{array}$ & $\begin{array}{c}5 \\
20\end{array}$ & $\begin{array}{c}4 \\
75\end{array}$ \\
\hline Theoretical air request for combustion, $\mathrm{kg} / \mathrm{kg}$ & 14.5 & 15.5 & 17.2 & 6.1 & 34.0 \\
\hline
\end{tabular}

In the case of petrol engines, the gaseous fuel can completely replace petrol fuel due to external ignition. In diesel engines, the diesel fuel is essential to initiate the ignition (dual-fueled engine) or applying the spark plug, then the engine can be powered only with gaseous fuel $[6,7]$. Due to the fact, that the diesel engine operates at the air excess, the delivering the gaseous fuel is possible in cylinder filling process at the expense of reduced air mass, containing oxygen, essential in combustion process. In this case the engine uses advantages of both fuels and is capable of operating with minimal interference in engine construction. The second case requires higher range of interfering with engine infrastructure, where the additional installation of subsystems responsible for ignition initialization (spark plug) and reducing the compression ratio are required.

That is why the attempt was made to create the simulation model of the diesel engine powered with admixture of LPG of different degrees. Modern, commercial solutions of LPG powering systems dedicated for diesel engines are meeting several operational problems. That is why the calculations were needed, basing on which, the conclusion about source of some engine issues was possible to draw.

Internal combustion engines used in road transportation are mostly compression ignition engines powered with diesel fuel. The delay of injection start, which initiates the ignition of dual-fuel engine (diesel/LPG) effects in increasing the efficiency and decreasing the hard work effect [8]. On the other hand, the knocking combustion occurs resulting in lowered durability, including failure wear [9]. The effect of the knock can be lowered by means of proper selection of diesel/LPG mixing ratio, lowering by this hydrocarbons and carbon monoxide emissions [10]. Increasing the preliminary dosage mass results in thermal efficiency increase, simultaneously increasing the possibility of knock, thus should it not be used in dual-fuel powering at maximal loads [11]. The negative influence of dualfuel powering on $\mathrm{CO}$ emission can be reduced by increasing the preliminary dosage as a result of lengthening the injection, however influences this the NOx emission increase [12].

Unfortunately, the dominant feature with LPG powering is the variability of chemical composition and pollution content, what influences on the diversity of toxic compounds emission to the atmosphere. In the paper [13] it was shown, that at proper LPG composition, the engine works smoothly with up to $90 \%$ ON dosage replaced by LPG. In general, engines powered with gaseous fuel are characterized by lower toxic compounds emission, as it is in the case of petrol or diesel engines, however in the results of some technical imperfections, the total emission increases compared to base fuel powering [14].

The amount of heat transferred with the exhaust 
gases to the diesel engine exhaust system is lower for the dual-fuel solution. Faster gas combustion in smaller combustion chamber volume causes the increase of maximum temperature and cycle pressure [15].

On the other hand, the CNG injection to the combustion chamber results in higher mechanical load as an effect of maximum pressure increase, comparing to $\mathrm{CNG}$ brought via intake manifold, where as bringing CNG via intake manifold results in increased thermal loads [16].

\section{The characteristics of research object and necessary conditions from simulation initialization}

The object of research is the compression ignition engine with parameters listed in Table 2 . The simulation research concerns the engine powered only by diesel fuel and powered by mixture of diesel and LPG in gaseous phase injected indirectly to the inlet duct during intake stroke.

For dual-fuel powering the system presented in Fig. 1 was applied, where the nozzle was inserted to support gaseous fuel to the intake manifold. The engine in intake stroke is partially powered with LPG, making the combustible mixture. The injection of diesel fuel at the final phase of compression stroke is responsible for ignition initiation.

In the next step of research, the following assumptions were applied:

a) constant wall temperature: $360^{\circ} \mathrm{K}$;

b) density of flowing gas is pressure and temperature dependent;

c) air with following properties:

- density in normal conditions $-1.205 \mathrm{~kg} / \mathrm{m}^{3}$,

- heating value $-1.005 \mathrm{~kJ} /\left(\mathrm{kg}{ }^{\circ} \mathrm{K}\right)$,

- thermal conductivity $-0.0259 \mathrm{~W} /\left(\mathrm{m}{ }^{\circ} \mathrm{K}\right)$,

- dynamic viscosity $-1.81 \mathrm{e}-05 \mathrm{~kg} / \mathrm{ms}$,

- kinematic viscosity $-1.506 \mathrm{e}-05 \mathrm{~m}^{2} / \mathrm{s}$,

- molecular weight $-28.96 \mathrm{~kg} / \mathrm{kmol}$;

d) gravity omitted;

e) turbulence model k-epsilon.

The simulation was conducted by using the transient option, which means that the parameters of medium flow are variable in time. The boundary conditions of the engine operation were applied as for driving with high loads.

Thus assumed:
- engine speed - $2000 \mathrm{rpm}$,

- intake pressure - 0.1 MPa,

- back pressure - 0.1 MPa.

Table 2

Engine technical data

\begin{tabular}{|l|l|}
\hline Engine type & CI, natural aspirated \\
\hline Number, configure of cylinders & 4, in-line \\
\hline Timing system & 2 valves per cylinder \\
\hline Displacement, $\mathrm{dm}^{3}$ & 1.896 \\
\hline Bore, $\mathrm{mm}$ & 79.5 \\
\hline Stroke, $\mathrm{mm}$ & 89.5 \\
\hline Connecting rod length, $\mathrm{mm}$ & 150 \\
\hline Compression ratio & 18 \\
\hline Maximum power, $\mathrm{kW}$ & 77 at $4400 \mathrm{rpm}$ \\
\hline Maximum torque, $\mathrm{Nm}$ & 250 at $1900 \mathrm{rpm}$ \\
\hline
\end{tabular}

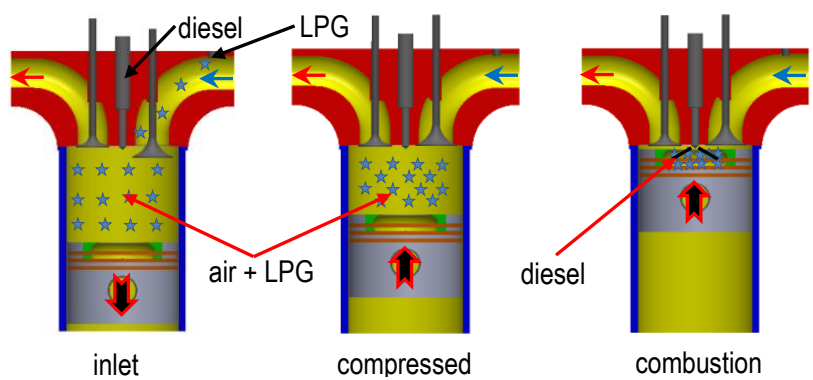

Fig. 1 Dual-fuel powering system schematics

For simulation initialization purposes, it was necessary to determine the valves timing and put it into the software workspace (Fig. 2).

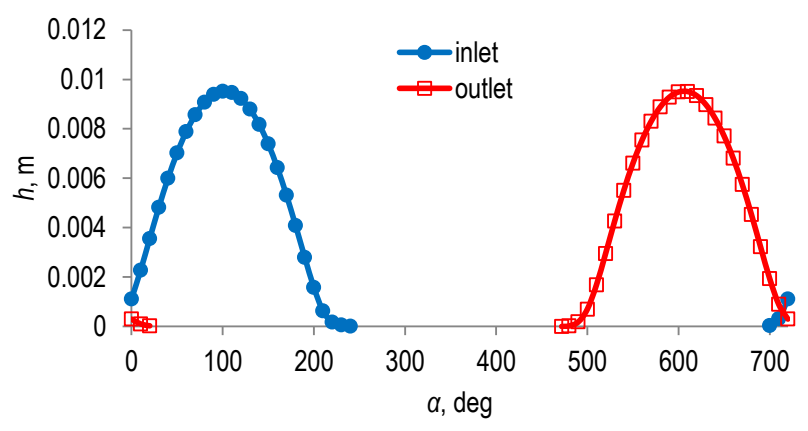

Fig. 2 The valve timing of the modeled engine

Table 3

Fuel injection parameters

\begin{tabular}{|l|l|l|l|l|}
\hline \multicolumn{2}{|c|}{ Parameter } & \multicolumn{1}{c|}{ Simulation 1 } & \multicolumn{1}{c|}{ Simulation 2 } & \multicolumn{1}{c|}{ Simulation 3 } \\
\hline Fuel type & diesel & diesel +LPG & diesel initial injection +LPG \\
\hline \multirow{2}{*}{ Injection angle $\left[{ }^{\circ} \mathrm{CA}\right]$} & diesel & $20^{\circ}$ & $10^{\circ}$ & $1^{\circ}$ \\
& LPG & - & 20 & $40^{\circ}$ \\
\hline \multirow{2}{*}{ Injection start angle $\left[{ }^{\circ} \mathrm{CA}\right]$} & diesel & $18^{\circ}$ before TDC & $18^{\circ}$ before TDC & $18^{\circ}$ before TDC \\
& LPG & - & $60^{\circ}$ after TDC & $60^{\circ}$ after TDC \\
\hline
\end{tabular}

As the initial conditions for the whole fluid computational space the constant pressure at value of $100 \mathrm{kPa}$, temperature at value of $290{ }^{\circ} \mathrm{K}$ and percentage composition of air with $21 \%$ content of oxygen, water steam of $0.5 \%$, carbon dioxide of $0.03 \%$ were applied.

The diesel fuel injection was assumed, in which the stream is cone-shaped with the apex angle of $120 \mathrm{deg}$, drop diameter of $40 \mu \mathrm{m}$, the mass flow of $4.5 \mathrm{gm} / \mathrm{s}$ and the stream velocity equal to $250 \mathrm{~m} / \mathrm{s}$. The LPG injection war realized by assuming the constant injection pressure of $70 \mathrm{kPa}$ and injector nozzle diameter of $2 \mathrm{~mm}$. The LPG composition was assumed as $50 \%$ of propane and $50 \%$ of butane. Injection times for specific variants are shown in Table 3. 


\section{The simulation research methodology}

For simulation research purpose the solid model was created, which corresponds to research object geometry, in which one full power cycle is possible to perform [17]. It consists of the volume, which is inside intake duct, combustion chamber and exhaust duct, this is the space in which flow processes occur (Fig. 3).

As an environment for model research the software was chosen, which bases on computational fluid dynamics (CFD) and uses the finite volume elements method - ANSYS Fluent. The model changes during simulation as a result of piston and valves displacement according to crankshaft movement and timing. The change of the computational space is possible due to dynamic mesh application. The simulation begins from the TDC of the piston, which corresponds to the angular crankshaft position at $0^{\circ}$ value.

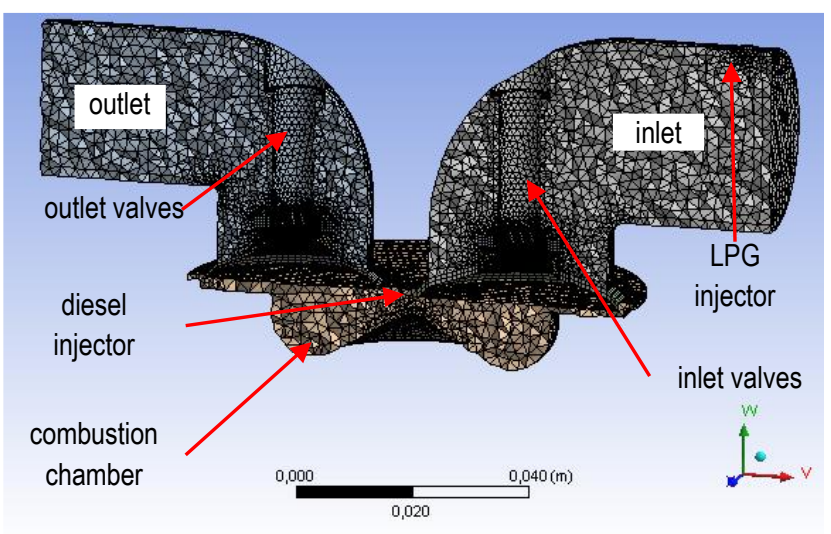

Fig. 3 View of model section with focused volume mesh applied

The finite volume mesh is built of about 300000 elements in TDC position and about 500000 in BDC position. The quality of the mesh is defined by means of statistical tool called Skewness, available in ANSYS Mesh module, of which the maximum value was 0.869 and the average 0.24 .

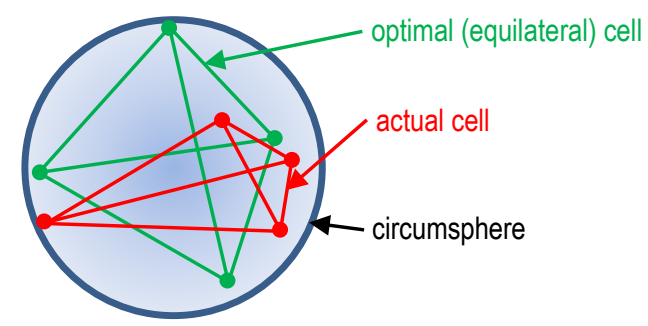

Fig. 4 Deviation from optimal equilateral volume [18]

Skewness has an influence on the mesh structure during rebuilding at consecutive time steps, the value of which stays on the assumed level, i.e. in this case 0.6. Skewness contained in proper range determines high quality of given results. For $3 \mathrm{D}$ models permissible values range from 0 to 0.95 . The ways of computing the parameter are shown in Figs. 4 and 5 and are represented accordingly by dependencies (1) and (2) for tetrahedronical cells and cells of other shapes.

$$
\text { Skewness }=\frac{\text { optimal cell size }- \text { cell size }}{\text { optimal cell size }},
$$

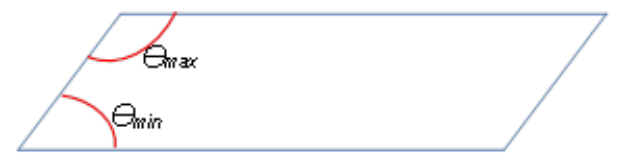

Fig. 5 Deviation from normalized angle [18]

$$
\text { Skewness }=\operatorname{MAX}\left[\frac{\theta_{\max }-\theta_{e}}{180-\theta_{e}}, \frac{\theta_{e}-\theta_{\min }}{\theta_{e}}\right] \text {, }
$$

The model has multisolid structure, it consists of ten separate solids. Multisolidness of the model is determined by ANSYS Fluent software requirements regarding variable geometry during simulation. The simplifications were not applied in the model, in the form of section of the elements or of symmetrical volume, which significantly shorten the calculation time, but are able to be applied in the case of predictible steady state research. In the analyzed case they are not applicable due to the turbulent flow character, strong air swirl during load exchange and uneven flame spread during combustion.

The model consists mainly of tetrahedral elements, which occur in solids marked in Fig. 6 by numbers $1,2,4,7,9$. It is needed to say that solid 9 is subjected to rebuild during the whole simulation, the other are constant. In solids 3, 5, 6, 8, 10 the hexaheddral elements occur with prismatic shape with quadrangular or triangular base, which are used accordingly to software requirements for getting in these areas cell extension or division, thus creation of new layers during movable elements movement.

This solution allows valve outline to displace without necessity of rebuilding solids 1 and 2 , which would be related to lengthening the calculation time. Between consecutive solids the interfaces are created letting maintain the continuity of the flow between displacing areas of various structure, or creating the wall out of the interface denying further flow in the time range corresponding to the valves closure.

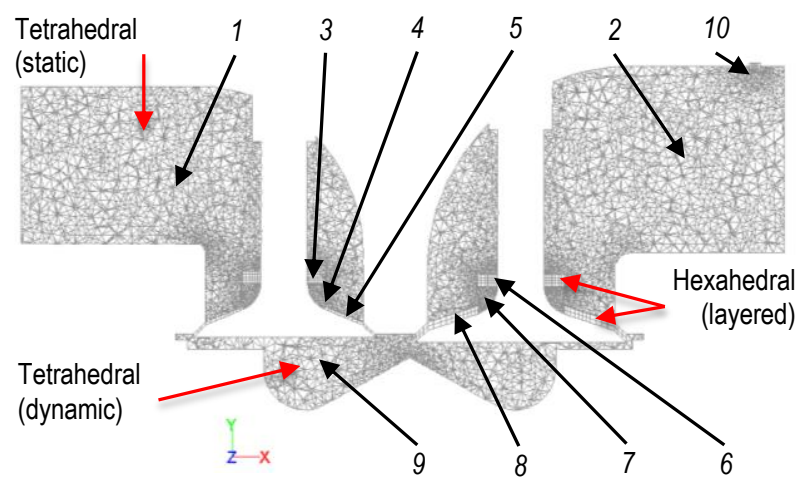

Fig. 6 Mesh types used in model

For simulating processes occuring inside the compression ignition engine the models were used, which are supplied by ANSYS Fluent software. The tool was used allowing initiating the combustion process as a result of compression ignition. It takes into account the amount of time passing from injecting the fuel to self-ignition occurence, i.e. the ignition lag, which is dependent on the 
parameters due to following formula [19]:

$$
\begin{aligned}
& \tau_{i d}=\left(\frac{C_{1}+0.22 \bar{S}_{p}}{6 N}\right) \times \\
& \times \exp \left(E_{a}\left(\frac{1}{R T}-\frac{1}{17.190}\right)+\left(\frac{21.2}{p-12.4}\right)^{e_{p}}\right),
\end{aligned}
$$

where $C_{1}$ is pro-exponential; $N$ is engine speed; $\bar{S}_{p}$ is mean piston speed; $E_{a}$ is effective activation energy; $R$ is universal gas constant; $T$ is temperature; $p$ is absolute pressure; $e_{p}$ is pressure exponent.

$$
E_{a}=\frac{E_{h h}}{C N+25},
$$

where $E_{h h}$ is activation energy; $C N$ is cetane number.

The combustion process was realized by using Eddy-dissipation model for turbulent models. The fuels are oxidated according to the reactions [20]:

$$
\begin{aligned}
& 2 \mathrm{C}_{10} \mathrm{H}_{22}+31 \mathrm{O}_{2}=20 \mathrm{CO}_{2}+22 \mathrm{H}_{2} \mathrm{O} \\
& \mathrm{C}_{3} \mathrm{H}_{8}+5 \mathrm{O}_{2}=3 \mathrm{CO}_{2}+4 \mathrm{H}_{2} \mathrm{O} \\
& 2 \mathrm{C}_{4} \mathrm{H}_{10}+13 \mathrm{O}_{2}=8 \mathrm{CO}_{2}=10 \mathrm{H}_{2} \mathrm{O}
\end{aligned}
$$

\section{Research results and discussion}

The speed distribution during cylinder filling (Fig. 7 - the case when cylinder is filled only with air) showed the correctness of dividing the fluid to components depending on prognosed work parameters gradients. The swirls can be observed in almost whole analyzed space (stream lines with velocity values). Maximum velocity values were noted at level of $17 \mathrm{~m} / \mathrm{s}$ in valve slot necking.
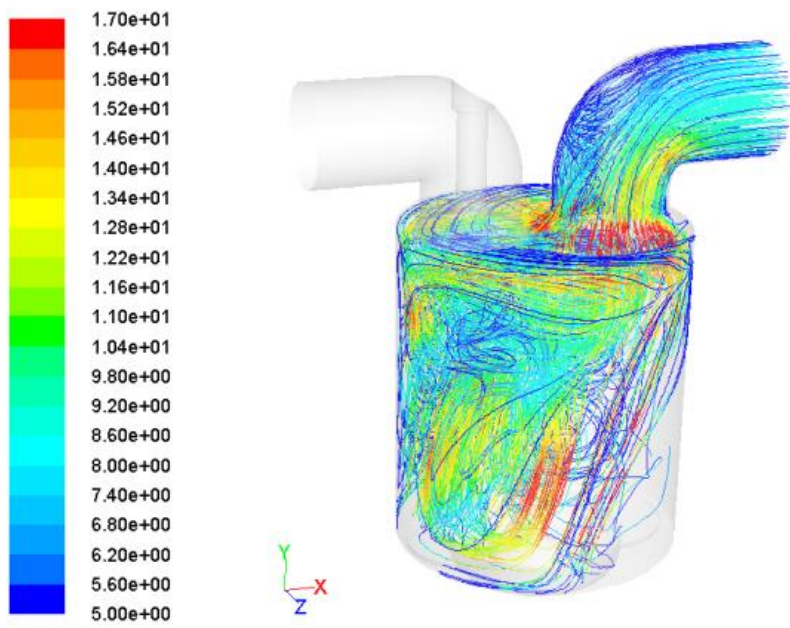

Fig. 7 Air flow velocity distribution $(\mathrm{m} / \mathrm{s})$ during cylinder filling - piston at $10^{\circ} \mathrm{CA}$ before $\mathrm{BDC}$

The average pressure and temperature courses show differences in the case of applying LPG admixture (Fig. 8 and 9). After occurence of ignition the pressure reaches greater gradient in the case of diesel+LPG, maximum value is higher by about $0.25 \mathrm{MPa}$ as well. This implies that the engine powered by LPG admixture is capable of reaching higher values of working indicators, i.e. torque.

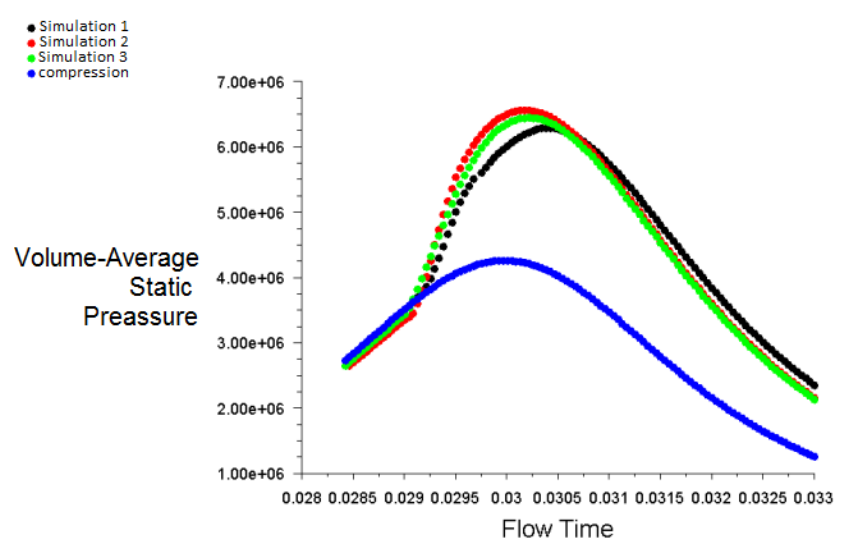

Fig. 8 Average static pressure course $(\mathrm{Pa})$ in cylinder (diesel and diesel + LPG)

The increase of temperature by about $50{ }^{\circ} \mathrm{K}$ is related to that (Fig. 9).

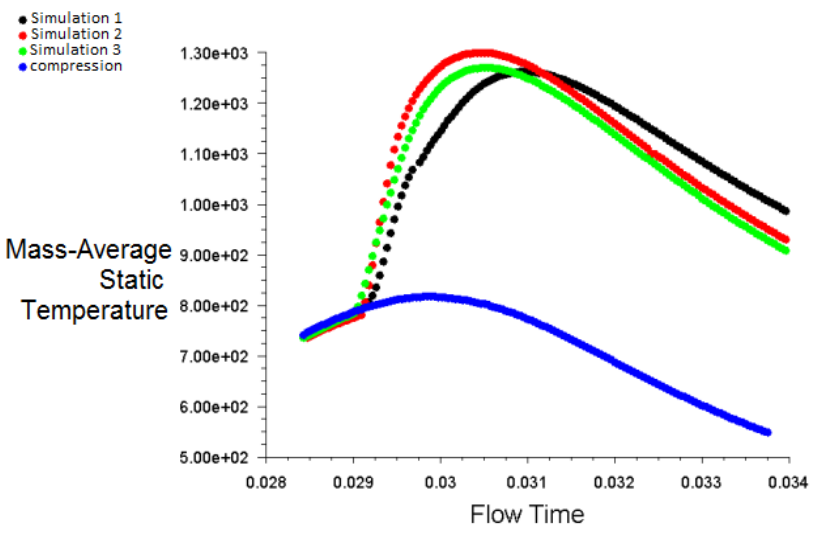

Fig. 9 Average temperature course $\left({ }^{\circ} \mathrm{K}\right)$ in cylinder (diesel and diesel + LPG)

That is why it requires monitoring the temperature in exhaust systems of engine of such type, what is practiced in commercial LPG system solutions.

Static pressure and temperature distributions at TDC for Simulation 1 (diesel) are presented in Fig. 10. The biggest pressure values occur in lower part of combustion chamber what is the result of proper directing of fuel streams. (Fig. 10, a and d). The temperature reaches the biggest values at the edges of the stream as well, according to the flame spread direction. The diesel fuel injection to the space filled with air admixtured by LPG show increased pressure in the area of the top part of combustion chamber, the similar thing occurs in the case of temperature (Simulation 2 - diesel+LPG - Fig. 10, b and e). Simulation 3 (diesel initial injection + LPG) shows the lowest pressure and temperature values, what causes the difficulties of reaching the indicators values at a level comparable with diesel powering.

The maximum value of reaction heat (Fig. 11) in beginning combustion phase in the case of Simulation 2 is significantly lower than in diesel (Simulation 1), the contrary situation occurs in the case of Simulation 3, where lowered amount of reaction heat value can be observed, what let conclude about lower thermal loads occuences for this kind of solution. 


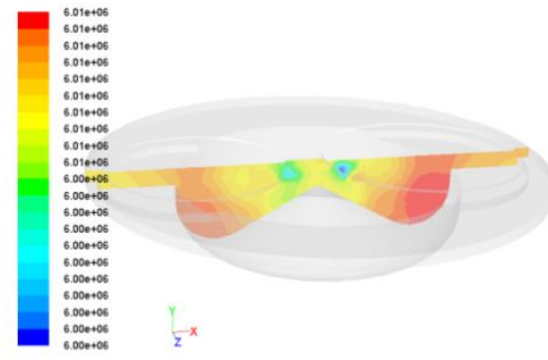

a

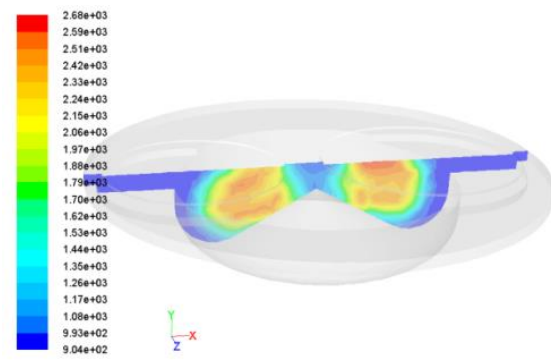

d
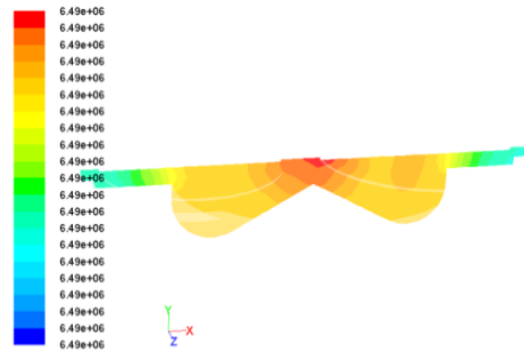

b
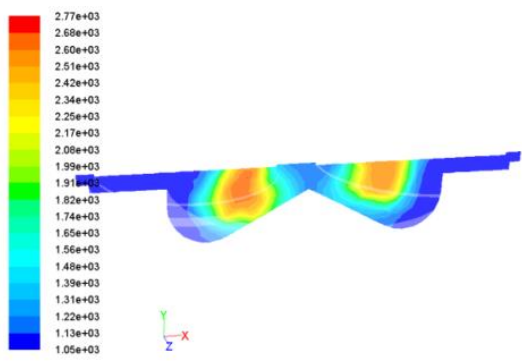

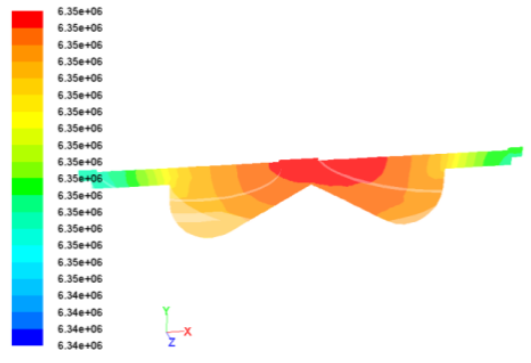

c

Fig. 10 Static pressure distribution $(\mathrm{Pa})$ and temperature distribution $\left({ }^{\circ} \mathrm{K}\right)$ in cylinder section at TDC piston position: a,d - diesel; b,e - diesel + LPG; c,f - diesel initial injection + LPG

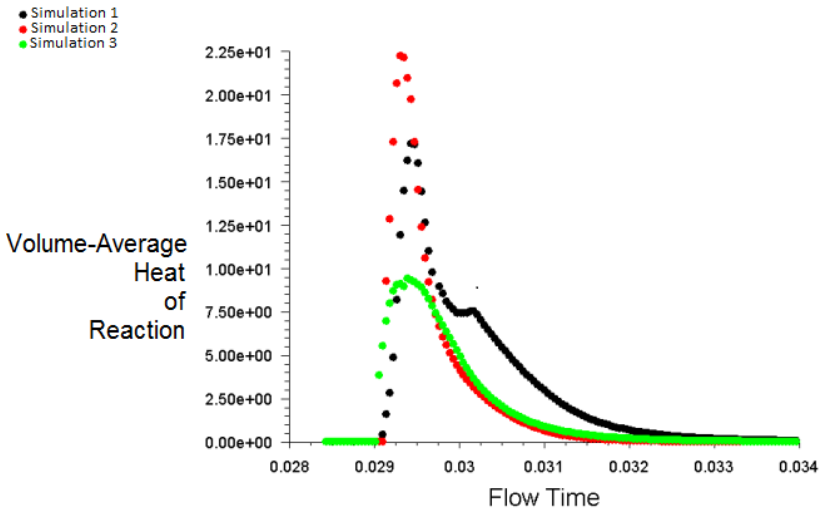

Fig. 11 Reaction heat course (W) for each simulation

\section{Conclusions}

Basing on the conducted research and analysis can be stated that:

1. The compression ignition engine works with air excess and is qualitative controlled, it is possible to supplement the supplying air with LPG admixture without negative influence on oxygen content necessary in combustion process.

2. Using the software based on computational fluid dynamics with finite volume method allows process analyzing of the engines in pre-prototype research.

3. Supplementing the air with LPG admixture during compression ignition engine filling results in increase both pressure and temperature during combustion process.

4. The temperature distribution at TDC after combustion initiation shows that in the case of diesel powering the combustion chamber walls (piston) are more heat loaded than in the case of powering LPG admixture or diesel initial injection + LPG.

5. The course of heat development in cylinder shows lengthening the process in the case of diesel powering, what can be the result of fuel cracking, the decay of the higher hydrocarbons to lower, which flame slower.

6 . In the following phase the charged engine simulations are planned to be conducted, because modern compression ignition power units are equipped with air supplying systems of such type., and commercial attempts of LPG applying as the admixture to the base fuel cause wear problems.

\section{Acknowledgment}

The investigations described in this paper are a part of the research project No $\mathrm{S} / \mathrm{WM} / 2 / 13$ realized at Bialystok University of Technology.

\section{References}

1. Lejda, K.; Jaworski, A. 2006. Gas fueling of agricultural engines, Motrol - Motorization and Power Industry in Agriculture 8: 131-138 (in Polish).

2. Gis, W.; Menes, W.; Waskiewicz, J. 2012. The analysis of the potential for the use of gaseous fuels in the municipal bus transport in Poland. Part 1, Combustion Engines 1(148): 17-26. PTNSS-2012-111.

3. Gis, W.; Menes, W.; Waskiewicz, J. 2012. The analysis of the potential for the use of gaseous fuels in the municipal bus transport in Poland. Part 2, Combustion Engines 3(150): 82-88. PTNSS-2012-SS3-302.

4. Lejda, K.; Jaworski, A. 2000. Gas fuelling problems of automotive engines, Proceedings of Vth International Scientific Conference Gas fueled engines 2000. Czestochowa, 229-246 (in Polish).

5. Lejda, K.; Jaworski, A. 2003. Gas fuelling problems of agricultural engines, Proceedings of International Conference Motrol Automotive and energetics in agriculture 5: 92-100.

6. Flekiewicz, M. 1999. Gas fuelling systems in trucks and buses, Fuels, Oils, Lubricants in Operation 66: 3740.

7. Zoltkowski, A.; Jarczewski, M. 2000. Adaptating 
diesel engines to gaseous fuel, Proceedings of Vth International Scientific Conference Gas fueled engines 2000, Czestochowa, 387-394 (in Polish).

8. Luft, S. 2001. The choice of control parameters dual fuel compression ignition engine fueled mainly liquid propane-butane, Journal of Kones Internal Combustion Engines 8(3-4): 53-59.

9. Luft, S.; Koziol, S. 2003. Selected results of dual fuel diesel engine fueled mainly fuel LPG, Journal of Kones Internal Combustion Engines 10(1-2): 163-171.

10. Kowalewicz, A. 2008. Adaptation of a diesel engine to the natural gas supply, Technical Transactions 7-M: 6778 (in Polish).

11. Abd Alla, G.H.; Soliman, H.A.; Badr, O.A.; Abd Rabbo, M.F. 2000. Effect of pilot fuel quantity on the performance of a dual fuel engine, Energy Conversion \& Management 41: 559-572. http://dx.doi.org/10.1016/S0196-8904(99)00124-7.

12. Papagiannakis, R.G.; Hountalas, D.T.; Rakopoulos, C.D. 2007. Theoretical study of the effects of pilot fuel quantity and its injection timing on the performance and emissions of a dual fuel diesel engine, Energy Conversion and Management 48: 2951-2961. http://dx.doi.org/10.1016/j.enconman.2007.07.003.

13. Saleh, H.E. 2008. Effect of variation in LPG composition on emissions and performance in a dual fuel diesel engine, Fuel 87: 3031-3039.

http://dx.doi.org/10.1016/j.fuel.2008.04.007.

14. Zoltowski, A. 2002. Emission problems of the car engines fuelled with LPG, CNG, Journal of Kones Internal Combustion Engines 1-2: 303-310.

15. Luft, S.; Michalczewski, A. 2002. Trying to explain to improve the overall efficiency of the diesel engine dually fueled mainly LPG, Journal of Kones Internal Combustion Engines 1-2: 164-172.

16. Michalowski R.; Miksiewicz, K.; Tkaczyk, M. 2012. Numerical analysis of comparative combustion engines CNG, Combustion Engines 1(148): 62-71. PTNSS2012-SS1-109.

17. Jemni, M.A.; Kantchev, G.; Abid, M.S. 2011. Influence of intake manifold design on in-cylinder flow and engine performances in a bus diesel engine converted to LPG gas fuelled, using CFD analyses and experimental investigations, Energy 36: 2701-2715. http://dx.doi.org/10.1016/j.energy.2011.02.011.
18. Ansys Fluent 12.1 Documentation 2009.

19. Hardenburg, O.F.; Hase, F.W. 1979. An empirical formula for computing the pressure rise delay of a fuel from its cetane number and from the relevant parameters of direct injection diesel engines, SAE Technical Paper 790493, SAE. http://dx.doi.org/10.4271/790493.

20. Rychter, T. 1990. Mathematical modeling of the working cycle piston engine, PWN, Warsaw (in Polish).

\section{G. Pulawski, D. Szpica}

\section{THE MODELLING OF OPERATION OF THE COMPRESSION IGNITION ENGINE POWERED WITH DIESEL FUEL WITH LPG ADMIXTURE}

\section{S u m m a r y}

The tendency to lower the vehicle usage costs forces the automotive industry to elaborate more efficient power units, able of consuming less fuel, or to lower the vehicle mass. In the case of commercial vans or trucks, the second trend has lower importance, because they are usually forecasted to move the load. This type of vehicles is mostly powered with compression ignition engines, that is why in the cheaper fuel needs to be used in the lowering costs course. Since a couple of years the interest of the LPG can be noticed on the market in this aspect, that is why the modeling of operation of the unit of such type was attempted. The simulation studies, with usage of the CFD software are the alternative to building prototype systems followed by the research with use of them. Computational capabilities of modern computers allow fast process analysis. In the research course three cases of compression ignition engine powering were analyzed. As a reference - diesel, as a comparison - diesel + LPG and diesel initial injection + LPG, showing the differences in process courses, which influence on operational capabilities

Keywords: internal combustion engine, alternative fuels, LPG, simulation research.

Received March 27, 2015

Accepted September 17, 2015 